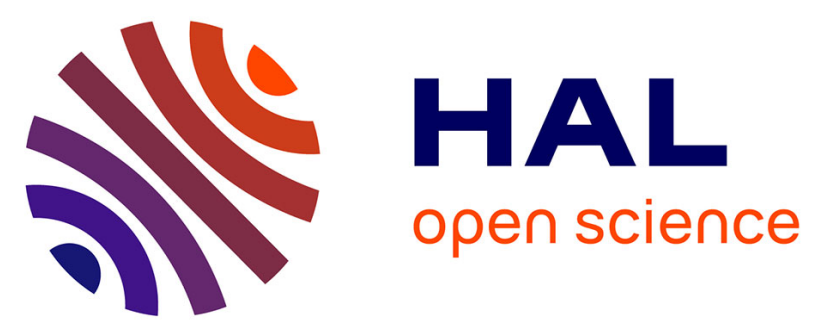

\title{
An environmentally realistic pesticide and copper mixture impacts embryonic development and DNA integrity of the Pacific oyster, Crassostrea gigas
}

Huong Mai, Jérôme Cachot, Christelle Clérandeau, Martin Caroline, Nicolas

Mazzella, Patrice Gonzalez, Bénédicte Morin

\section{To cite this version:}

Huong Mai, Jérôme Cachot, Christelle Clérandeau, Martin Caroline, Nicolas Mazzella, et al.. An environmentally realistic pesticide and copper mixture impacts embryonic development and DNA integrity of the Pacific oyster, Crassostrea gigas. Environmental Science and Pollution Research, 2020, 27 (4), pp.3600-3611. 10.1007/s11356-018-3586-6 . hal-03066007

\section{HAL Id: hal-03066007 https://hal.inrae.fr/hal-03066007}

Submitted on 5 Jan 2021

HAL is a multi-disciplinary open access archive for the deposit and dissemination of scientific research documents, whether they are published or not. The documents may come from teaching and research institutions in France or abroad, or from public or private research centers.
L'archive ouverte pluridisciplinaire HAL, est destinée au dépôt et à la diffusion de documents scientifiques de niveau recherche, publiés ou non, émanant des établissements d'enseignement et de recherche français ou étrangers, des laboratoires publics ou privés. 
1 An environmentally realistic pesticide and copper mixture impacts embryonic

3

4

6

\section{development and DNA integrity of the Pacific oyster, Crassostrea gigas}

Huong Mai ${ }^{1,2}$, Jérôme Cachot $^{1}$, Christelle Clérandeau ${ }^{1}$, Caroline Martin ${ }^{3}$, Nicolas Mazzela ${ }^{3}$, Patrice Gonzalez ${ }^{1}$, Bénédicte Morin ${ }^{1 *}$

${ }^{1}$ Univ. Bordeaux, EPOC, UMR 5805, F-33400 Talence, France

${ }^{2}$ University of Science and Technology of Hanoi, WEO Department, Hanoi, Vietnam

${ }^{3}$ IRSTEA, UR EABX, F-33612 Cestas, France

* Corresponding author: Tel.: +33 (0) 540002 256, Fax: +33 (0) 540008 719, benedicte.morin @u-bordeaux.fr

\section{Abstract}

Frequent occurrences of pesticides in the environment have raised concerns that combined exposure to these chemicals may result in enhanced toxicity through additive or synergistic interaction between compounds. Spermatozoa and embryos of the Pacific oyster, Crassostrea gigas, were exposed to different concentrations of a pesticide mixture with and without copper, mimicking the cocktail of pollutants occurring in the oyster culture area of Arcachon Bay. For the $1 \mathrm{X}$ exposure condition, measured concentration corresponds to a total concentration of $1.083 \mu \mathrm{g} \mathrm{L}^{-1}$ for the mixture of 14 pesticides and to $6.330 \mu \mathrm{g} \mathrm{L}^{-1}$ for copper $(\mathrm{Cu})$. Several endpoints, including larval abnormalities, DNA damage to spermatozoa and embryo and gene expression in D-larvae were investigated. Results demonstrated that pesticide mixtures in combination with or without copper induced a dose-dependent increase in embryotoxic and genotoxic effects on D-larvae from the lowest tested dose of $0.1 \mathrm{X}$. Transcription of genes involved in anti-oxidative stress (cat), respiratory chain (coxI), metal detoxification ( $m t 1$ and $m t 2)$ and cell cycle arrest and apoptosis (p53) was found to be significantly downregulated while the xenobiotic biotransformation gene $g s t$ was significantly upregulated in embryos exposed to pesticide mixture with and without $\mathrm{Cu}$. These findings raise the question of the possible impacts of mixtures of pesticides and metals on wild or farmed oyster populations from polluted coastal marine areas.

Keywords: pesticide mixture, copper, gene expression, genotoxicity, embryotoxicity, Pacific oyster 


\section{Introduction}

For several decades, coastal ecosystems have been subjected to increased copper $(\mathrm{Cu})$ and pesticide contamination, mainly from agricultural practices and antifouling paints used on boats (Martinez et al, 2001; Konstantinou et Albanis 2004). About 4.6 million tons of pesticides are applied yearly into the environment throughout the world (Ansari et al, 2014) and many of them inadvertently are discharged in aquatic ecosystems. Some pesticides are hydrophobic compounds, which tend to bind to suspended particulates and dissolved organic matter, accumulating in sediments and aquatic biota (Brooks et al, 2007; Thomas and Brooks 2010). Others are more hydrophilic and less persistent in aquatic ecosystems (Lamoree et al, 2002). Pesticides are found in water bodies such as lakes, rivers, streams and other surface waters that support aquatic life (Gilliom 2007); as a consequence, the receiving ecosystem is invariably contaminated with multiple pesticides. Since at least the $19^{\text {th }}$ century, $\mathrm{Cu}$ has been used as a fungicide in vineyards (Komarek et al, 2010). Copper is also used in boat hull painting as a replacement for tributyltin (TBT) (Konstantinou et Albanis, 2004). As a consequence $\mathrm{Cu}$ can be found at concentrations up to $2000 \mu \mathrm{g} \mathrm{g}^{-1}$ in sediment within severely polluted areas (Bryan and Langston 1992; Legorburu and Canton 1991). Concentrations of pesticides and copper measured in surface water and bed sediment frequently exceeded waterquality benchmarks for aquatic life (Geffard et al, 2002; Gilliom 2007). Several previous toxicity studies have demonstrated that pesticides and trace metals such as $\mathrm{Cu}$ can impair water quality and cause adverse effects on aquatic species, in particular at the early developmental stages of invertebrates (Akcha et al. 2012; Mai et al. 2012, Manzo et al. 2006). However, these mainly focus on the impacts of individual pesticides, but few data are available on the toxicity of mixtures of pesticides in combination with or without copper to marine molluscs. The exposure of animals in ecosystems to pesticides is never limited to a single compound, but to a complex mixture of chemicals from a variety of sources. Therefore, the frequent co-occurrence of pesticides and copper in the environment has raised concern over the combined exposure to these chemicals that would result in toxicity modulation due to synergistic, additive or antagonistic effects of chemicals (Monosson 2004).

Assessing the toxicity of pesticides in mixtures has been an enduring challenge in environmental health research for the past few decades (Monosson 2004). Interaction effects can be seen when small and statistically insignificant effects of separate compounds are added to induce statistically significant effects when these compounds are mixed (Gagnaire et al. 
2006). Indeed, one chemical can affect the toxicity of others not only through molecular interactions but also by influencing their adsorption, distribution and excretion, biotransformation, and bioavailability (Altenburger et al. 2003). The persistence of a number of pesticides may be changed when used in combination with other pesticides (Vischetti et al. 1996). The toxic effect of multiple chemicals has been recognized as an important factor in ecotoxicology, because mixtures can have a greater negative impact than the individual constituents of the mixture (Hernando et al. 2003, Faust et al. 2001, Poletta et al. 2011). Indeed, the effect of a mixture of pesticides on the phagocytosis competence of $C$. gigas haemocytes was truly demonstrated, while no effect was induced when compounds were tested separately (Gagnaire et al. 2007, Gagnaire et al. 2006). At present, few studies have investigated pesticide mixture or heavy metal mixture toxicity on aquatic species (Gagnaire et al. 2007; Hernando et al. 2003; Junghans et al. 2003; Manzo et al., 2008; Verslycke et al. 2003), but no study has focused on the effects of pesticide mixture in combination with copper. The risk assessment process is complicated by the fact that environmental exposure frequently involves mixtures of chemicals rather than a single compound.

Embryotoxicity and genotoxicity (comet assay) assays have been widely used to estimate the deleterious effects of contaminants on bivalve mollusc larvae and embryos (His et al. 1999). Indeed, oyster embryos and larvae have been proposed as model organisms for marine ecotoxicological tests (Geffard et al. 2002; His et al. 1999; Wessel et al. 2007) because of the year-round availability of fertilized eggs from adult breeding Crassostrea gigas oysters. However, to our knowledge, few papers have investigated molecular responses in terms of gene expression in oyster larvae and embryos exposed to pollutants (Huong et al, 2014). It is well known that combined measurement of biomarkers can offer more complete and biologically more relevant information on the potential impact of contaminants on the health of organisms (van der Oost et al. 1996). In this respect, the measurement of a large panel of biomarkers in oyster larvae may constitute a useful tool to understand the modification of oyster physiology due to the environment. In the present study, C. gigas embryos or sperm were exposed to environmentally realistic mixtures of pesticides both with and without added copper. These mixtures were representative of those detected in Arcachon Bay (Auby et al. 2007; Budzinski et al. 2011; Diepens et al. 2017; Gamain et al. 2016, 2017a, b) and responses were investigated from the molecular level to the individual level.

\section{Materials and methods}




\subsection{Chemicals and seawater}

Fifteen reference toxicants (14 pesticides and $\mathrm{CuSO}_{4}$ : Table 1), formalin and DMSO (dimethyl sulfoxide) with purity greater than 96\% were purchased from Sigma-Aldrich Chemical (St. Quentin Fallavier, France). Dispase II, Triton X-100, low melting point (LMP) agarose, normal melting point (NMP) agarose, and MEM-alpha (Minimum Essential Medium) were purchased from Gibco (Invitrogen, Cergy Pontoise, France). Formic acid $(\mathrm{HCOOH})$, ammonium acetate and organic solvents (methanol - $\mathrm{MeOH}$ - and acetonitrile ACN- ULC grade) were purchased from Biosolve (Dieuze, France).

Seawater was collected from Grand Banc station in the Arcachon Bay (SW France) on September 2015, an area with a naturally reproducing population of oysters. Immediately after sampling, seawater was filtered at $0.2 \mu \mathrm{m}$ to eliminate debris and microorganisms. Salinity was measured at 33 using a salinity probe (Wissenschaftlich Techische Werkstätten Multi 340i, sonde TetraCon 325). Filtered seawater (FSW) was stored at $4{ }^{\circ} \mathrm{C}$ in darkness and was used within 3 days. A few hours before experiment, FSW was filtered again at $0.2 \mu \mathrm{m}$.

\subsection{Animals}

Mature oysters (Crassostrea gigas, Thunberg, 1793) came from a commercial hatchery specialized in the production of mature oysters year-round (Guernsey Sea Farms, UK). Oysters were kept at around $10{ }^{\circ} \mathrm{C}$ for transportation and then acclimatized in FSW before the beginning of experiments. All oysters were used within 3 days.

\subsection{Preparation of pesticide and copper solutions}

Stock solutions $\left(100,250\right.$ or $\left.1,000 \mathrm{mg} \mathrm{L}^{-1}\right)$ were prepared in either dimethyl sulfoxide (DMSO), or acetonitrile, or milli-Q water depending on their solubility characteristics. Water was spiked with a mixture of 14 pesticides only (PM) or the same pesticide mixture in combination with copper $(\mathrm{PM}+\mathrm{Cu})$, or copper only $(\mathrm{Cu})$ in a concentration range of 0 (solvent control), $0.1 \mathrm{X}, 1 \mathrm{X}, 10 \mathrm{X}$ and $100 \mathrm{X}$ with $1 \mathrm{X}$ representing the environmental concentration of pesticides mixture (for a total nominal concentration of $1.557 \mu \mathrm{g} \mathrm{L}^{-1}$ and $2 \mu \mathrm{g} \mathrm{L}^{-1}$ for copper ) in Arcachon Bay (Auby et al. 2007; Budzinski et al. 2011; Diepens et al. 2017, Gamain et al. 2016, 2017a, b) (Table 1). Negative control was FSW spiked with solvent DMSO and acetonitrile at final solvent total concentration less than $0.01 \%$. Three or four replicates were performed for each tested condition. 


\subsection{Chemical analysis}

Chemical analysis were performed with FSW control or spiked before the embryotoxicity test.

\subsubsection{Pesticides}

Sample extraction

137

500-mL control and 100-mL spiked water samples ( $\mathrm{pH}$ adjusted at 5 with $10 \%$ nitric acid solution) were filtered using GF/F glass microfiber filters $(0.7 \mu \mathrm{m}$ pore size, Whatman). Before analysis, pre-concentration of the analytes was performed using Solid-Phase Extraction (SPE) with $150 \mathrm{mg}$ Oasis HLB cartridges (Waters), according to the method described elsewhere (Lissalde et al. 2011; Fauvelle et al. 2015). Elutions were achieved with $3 \mathrm{~mL}$ of methanol, followed by $3 \mathrm{~mL}$ of a mix of methanol: ethyl acetate (75:25, v/v). $2.5 \mu \mathrm{L}$ of a solution of internal standards (atrazine d5, carbofuran d3, DEA d6, diuron d6, metolachlor d6, pirimicarb 6 and MCPA d3) at $1 \mathrm{ng} \mu \mathrm{L}^{-1}$ was then added to the 6-mL extracts, followed by a solvent evaporation under a gentle stream of nitrogen, and then dissolved in either $250 \mu \mathrm{L}$ of UPW and ACN (90:10, v/v) prior to UPLC-ToF analysis or $250 \mu \mathrm{L}$ of UPW and $\mathrm{ACN}(5: 95, \mathrm{v} / \mathrm{v})$ prior to HILIC-MS/MS analysis.

\section{Instrumentation and data processing}

UPLC-ToF analyzes were performed by liquid chromatography ACQUITY UPLC H-Class coupled to a Xevo G2-S TOF-MS (Waters) as described in Gamain et al. (2017a). Data treatment was performed with MassLynx v4.1 and a library of 45 pesticides was used for the target screening. Ion extraction was performed with $10 \mathrm{mD}$ a mass window at the expected retention time $( \pm 0.2 \mathrm{~min})$. One or two fragments were used for the confirmation (S1). HILICMS/MS analyses were performed with liquid chromatography Dionex Ultimate 3000 coupled to API 2000 tandem mass spectrometer (Sciex) according to the method described in Fauvelle et al. 2015.

\section{Method validation and quality controls}


Our analytical method was validated based on calibration linearity, extraction recovery, and Limits of Quantification (LOQ) according to the French standard NF T90-210. Recoveries and LOQs are shown in S1 for the detected compounds into the different samples. For quality control, SPE and POCIS blanks were routinely controlled, and the recoveries of two levels of spiked mineral water (e.g. 40 and $200 \mathrm{ng} \mathrm{L}^{-1}$ ) were evaluated for each batch. Periodic checking of two calibrating standards (e.g. 2 and $25 \mu \mathrm{g} \mathrm{L}^{-1}$, every 10 samples) and analytical blanks was also performed.

\subsubsection{Copper}

30-mL water sample was immediately acidified with 5\% final of nitric acid (Nitric acid $65 \%$, Fluka). Samples were then analysed by Inductively-Coupled Plasma Optic Emission Spectrometry (ICP-OES, Vista Pro, Agilent Technologies) and by Inductively-Coupled Plasma Mass Spectrometry (ICP-MS, Xseries2, Thermofisher Scientific) as described in Gamain et al, 2017a.

\subsection{Embryotoxicity assay}

Embryo assays were carried out on $\mathrm{PM}$ and $\mathrm{PM}+\mathrm{Cu}$ mixtures but not on $\mathrm{Cu}$ alone since data were already available (Mai et al. 2012). The oyster embryotoxicity assay has been described in detail previously (Gamain et al. 2016). Each embryotoxicity assay was performed in duplicate with two different batches of oyster embryos $(\mathrm{N}=4)$. A positive control was added for each embryotoxicity test with copper sulfate at $10 \mu \mathrm{g} \mathrm{L}^{-1}$ corresponding to the EC $_{-50}$ value as mentioned in the AFNOR procedure. An important prerequisite to validate the test was the presence, in control condition $\left(24{ }^{\circ} \mathrm{C}\right.$ in the absence of contamination) of less than $20 \%$ of abnormal larvae.

\subsection{Comet assay}

Data on copper genotoxicity was published previously (Mai et al. 2012). Comet assay for all the other conditions was performed in triplicate on cells obtained from unshelled larvae. Cell dissociation was carried out as previously described in Mai et al. 2014. 
Comet assay was also performed on oyster sperm cells. About 500,000 cells per replicate were exposed for $30 \mathrm{~min}$ at $24{ }^{\circ} \mathrm{C}$ in the dark to $5 \mathrm{~mL}$ of the tested solutions. Three replicates were performed per condition.

The comet assay was performed on isolated cells from larvae and sperm cells as described by Morin et al. (2011) and Mai et al. (2014).

\subsection{Gene expression}

Selected genes are involved in different cellular processes including cell cycle control and apoptosis (p53), xenobiotic biotransformation and excretion (cyp1a, gst, mxr), mitochondrial metabolism (cox, 12S), oxidative stress response (sodmt, cat) metal detoxification (mt1, mt2). Beta actin was used as a reference gene (Table 2).

After oyster embryos exposure to the pesticide mixture or $\mathrm{PM}+\mathrm{Cu}$ or $\mathrm{Cu}$ alone at $0.1 \mathrm{X}$, $1 \mathrm{X}$ and $10 \mathrm{X}$ for $24 \mathrm{~h}$, the density of larvae was determined. Three replicates for each contamination condition were performed and each replicate contained a total of 35,000 oyster larvae. Larvae solutions were then concentrated for RNA extraction, by centrifugation at $4,000 \mathrm{~g}$ for $10 \mathrm{~min}$ at $4^{\circ} \mathrm{C}$. The pelleted larvae were resuspended in $500 \mu \mathrm{L}$ of "RNA later" buffer (Qiagen). Those samples were then stored at $-80{ }^{\circ} \mathrm{C}$ until required.

Total RNA was extracted using the "Absolutely RNA ${ }^{\circledR}$ Miniprep" Kit (Stratagene, Agilent) according to manufacturer's instructions (including Dnase I treatment). First strand cDNA was synthesized from total RNA $(1 \mu \mathrm{g})$ using the "Affinity Script ${ }^{\mathrm{TM}}$ Multiple Temperature cDNA synthesis" kit (Agilent, Stratagene).

After extraction and reverse transcription, real-time PCR reactions were performed using Mx3000P (Stratagene) following the manufacturer's instructions. Detailed protocols are available in Mai et al. (2014).

\subsection{Statistical analysis}

Data is expressed as means \pm standard error (S.E). Statistical software SPSS (16.0) was used for data analysis. Normality of data distribution was tested on data residues using the Shapiro-Wilk test $(\mathrm{p}<0.01)$ while homogeneity of variance was checked using Levene's test $(\mathrm{p}<0.05)$. Once it had been confirmed that these two conditions were fulfilled, statistical analyses were performed by One-way Analysis of Variance (ANOVA). Differences among 
conditions were then performed using the Tukey's post hoc test. Significance difference was accepted at $\mathrm{p}<0.05$. The $\mathrm{EC}_{50}$, defined here as the toxicant doses causing $50 \%$ reduction in the embryogenesis success, and their 95\% confidence intervals (CI) were calculated by PRISM 5 software (GraphPad Software, California, USA).

\section{Results}

\subsection{Chemical exposure}

Measured concentrations of pesticides and copper in the different assays are reported in Table 1. Chlorothalonil and dichlofluanid could not be analysed by LC-ToF or LC-MS/MS, but were added to the mixture (at the nominal concentration) since they have been previously detected into the Arcachon Bay (Budzinski et al. 2011). Reference FSW from the Grand Banc station in the Arcachon Bay was shown to contain detectable but low levels of metolachlor, metolachlor ESA, acetochlor, diuron and irgarol, generally lower than the concentrations of the $0.1 \mathrm{X}$ condition. Background copper level measured in the reference seawater was around $3 \mu \mathrm{g} \mathrm{L}{ }^{-1}$. For the $0.1 \mathrm{X}$ and $1 \mathrm{X}$ conditions, the measured $\mathrm{Cu}$ concentrations reached $4.1 \mu \mathrm{g} \mathrm{L}^{-1}$ and $6.3 \mu \mathrm{g} \mathrm{\textrm {L } ^ { - 1 }}$ respectively which is higher than expected since it also included the $\mathrm{Cu}$ initially present in the reference seawater. For all pesticides and copper concentrations, except the carbendazim, a dose-depend increase was observed from the $0.1 \mathrm{X}$ to the $100 \mathrm{X}$ exposure condition.

\subsection{Embryotoxic effects}

The embryo-larval assay revealed that pesticide mixtures (PM) and $\mathrm{PM}+\mathrm{Cu}$ induced embryotoxic effects on oyster embryos, with some differences in the level of responses (Fig. 1). Embryotoxicity was detected at the lowest tested dose of $0.1 \mathrm{X}$ for $\mathrm{PM}$ and $\mathrm{PM}+\mathrm{Cu}(\mathrm{p}<$ 0.0001). In addition, a dose-dependent increase of abnormal D-larvae was observed. When comparing both pesticide mixtures with or without spiked $\mathrm{Cu}$, the percentage of abnormal larvae was not statistically different even for the two lowest concentrations ( $0.1 \mathrm{X}$ and $1 \mathrm{X})$. Larval abnormalities reached $100 \%$ at the highest tested dose $(100 \mathrm{X})$ for the $\mathrm{PM}+\mathrm{Cu}$ exposure, while it reached approximately $78.1 \%$ for the same dose of PM exposure.

Values causing a 50\% reduction in embryogenesis success $\left(\mathrm{EC}_{50}\right)$ and their $95 \%$ confidence intervals (CI) were reported in Table 3. The mixture of pesticides gave an $\mathrm{EC}_{50}$ 
value of $0.7 \mathrm{X}$ for $\mathrm{PM}+\mathrm{Cu}$, whereas the $\mathrm{EC}_{50}$ for the $\mathrm{PM}$ alone was $5.2 \mathrm{X}$. The $\mathrm{EC}_{50}$ value was $12.5 \mu \mathrm{g} \mathrm{L}^{-1}$ for $\mathrm{Cu}$ alone (Mai et al. 2012).

\subsection{Effects on DNA integrity (comet assay)}

A statistically significant increase in DNA damage in exposed-embryos was observed from the lowest dose of $\mathrm{PM}$ and $\mathrm{PM}+\mathrm{Cu}(0.1 \mathrm{X})$ compared to the control groups $(\mathrm{p}<0.001)$ (Fig. 2A). The percentage of tail DNA also increased in a dose-dependent manner for both mixtures. DNA damage appeared significantly higher at the highest dose (100X) for $\mathrm{PM}+\mathrm{Cu}$ in comparison to PM treatment. It was not the case at lower doses. Indeed, at the highest tested dose (100X), PM exposure induced $27 \%$ of tail DNA, against $37 \%$ for the same dose group of $\mathrm{PM}+\mathrm{Cu}$.

In the exposed-sperm experiment, a significant dose dependent increase of DNA damage was observed for both PM and PM+Cu exposures (p < 0.001) (Fig. 2B). A significant increase of tail DNA levels was measured from the lowest dose of both $\mathrm{PM}$ and $\mathrm{PM}+\mathrm{Cu}$ exposures. Statistical analysis revealed no significant differences in DNA damage between PM and $\mathrm{PM}+\mathrm{Cu}$ treatments.

\subsection{Gene transcription levels}

Transcription levels of 11 genes involved in several cellular mechanisms were analysed by quantitative RT-PCR in embryos after exposure to $\mathrm{PM}$ and $\mathrm{PM}+\mathrm{Cu}$ mixtures. The $\beta$-actin gene was used as a reference gene. The results of this analysis are reported in Table 4.

For oyster embryos exposed to $\mathrm{Cu}$ only, no transcription modulation of selected genes involved in mitochondrial metabolism (coxI, 12s), cell cycle arrest (p53) and detoxification $(m t 1, m t 2, \quad m x r)$ was observed at any tested concentrations. However, $\mathrm{Cu}$ induced overexpression of cyplA gene (IF = 1.8) at the highest tested concentration $(10 \mathrm{X})$.

For oyster embryos exposed to the pesticide mixture, a significant repression of coxI, mtl, $m t 2$ and $p 53$ genes at all tested doses was noted. Surprisingly, a significant repression of cat gene was observed only at $0.1 \mathrm{X}$ and $1 \mathrm{X}$ concentrations of PM.

Exposure of oyster embryos to $\mathrm{PM}+\mathrm{Cu}$ resulted in a significant induction of $g s t$ gene $(\mathrm{p}<$ 0.05), with IF values from 3.1 to 5.5. In contrast, the cat gene was significantly repressed (IF $=0.1-0.4)$ at all tested doses $(\mathrm{p}<0.05)$. The two metallothionein genes (mt1 and $m t 2)$, coxI 
gene and cat gene were overexpressed at $1 \mathrm{X}$ and $10 \mathrm{X}$ doses. Finally, the $p 53$ gene was significantly repressed at $0.1 \mathrm{X}$ and $10 \mathrm{X}$ doses $(\mathrm{p}<0.05)$.

\section{Discussion}

Pesticides are designed to selectively eliminate various pests including fungi, plants or animals. They usually target specific biological functions of the pest through disruption of vital cellular pathways. Their mechanisms of action are tightly linked to their chemical structures which are highly diverse. Although animals are exposed to complex mixtures of pollutants in the environment, most laboratory experiments are based on the use of a unique or binary mixture of molecules. Studies on pesticide mixtures (Faust et al. 2001, Poletta et al. 2011) have shown that mixtures generally exhibit higher toxicity than single compounds. Indeed, the effect of a mixture of pesticides on the phagocytosis competence of $C$. gigas haemocytes was truly demonstrated, while no effect was induced when compounds were tested separately (Gagnaire et al. 2007, Gagnaire et al. 2006). At present, few studies have investigated pesticide mixture or heavy metal mixture toxicity on aquatic species (Gagnaire et al. 2007; Hernando et al. 2003; Junghans et al. 2003; Manzo et al., 2008; Verslycke et al. 2003), but no study has focused on the effects of pesticide mixture in combination with copper.

\subsection{Embryotoxicity}

The toxicity of copper alone, metolachlor and its metabolites, irgarol and diuron for oyster embryos has already been investigated in previous studies (Mai et al. 2012, 2013). EC50 values of 12.5, 2332, 196 and $672 \mu \mathrm{g} \mathrm{L}^{-1}$ were obtained for copper (Mai et al., 2012), diuron, irgarol and metolachlor (Mai et al. 2013), respectively. In the present study a hundred percent of abnormal larvae was obtained at the highest dose group (100X) of $\mathrm{PM}+\mathrm{Cu}$ and $78.1 \%$ at the same dose of PM without spiked $\mathrm{Cu}$. At concentrations occurring in the Arcachon Bay (1X), $54 \%$ of abnormalities were obtained for the $\mathrm{PM}+\mathrm{Cu}$ treatment and $32.4 \%$ for the PM without $\mathrm{Cu}$. These results clearly indicate: (i) the higher toxicity of mixture of pollutants in comparison to pollutants alone and (ii) the likelihood of deleterious effects of environmental concentrations of mixture of pollutants. Faust et al. (2001) and Poletta et al. (2011) have reported higher toxicity for mixture of pesticides than for the single compounds. In the case of cumulative toxic effects, each chemical in the mixture can contribute to the overall toxicity in 
proportion to its toxic unit and ratio even if it is present at concentrations below the threshold of statistically detectable effects (Jacobsen et al. 2012; Silva et al. 2002). For compounds with dissimilar modes of action, the effects of each individual chemical may be directly opposed and the effects of the mixtures are more difficult to predict (Jacobsen et al. 2012). For compounds with similar mode of action, mixture could lead to much higher toxicity than predicted for additive effects. For example, in binary combination metolachlor elevated the toxicity of chlorpyrifos by 1.5 -fold in the aquatic midge (Jin-Clark et al. 2008). However, Manzo et al. (2008) reported that irgarol, diuron and copper in ternary mixtures were more toxic than diuron and less toxic than irgarol and copper when tested alone for sea urchin embryos. These authors also noted that the mixture was less toxic than the single contaminants when considering the NOEC obtained on embryos. The knowledge of a chemical mode of action is essential for understanding how mixtures may act jointly. Mode of action of certain pesticides are well known, in particular herbicides in photosynthetic organisms such as algae species (Backhaus et al. 2004; Ranke and Jastorff 2000), but there is much little information about the mechanisms of action of pesticides on aquatic animal species.

\subsection{DNA damage in oyster sperm and embryos}

Gametes are released directly into seawater and are thus exposed to all environmental pollutants present during spawning. It is of particular interest to study because this creates the potential for contaminants to disrupt fertilization processes. A significant increase of DNA damage in both exposed-sperm and exposed-embryos was observed following the exposure to $\mathrm{PM}$ and $\mathrm{PM}+\mathrm{Cu}$ from the lowest tested dose $(0.1 \mathrm{X})$. The $\mathrm{PM}+\mathrm{Cu}$ treatment induced a slightly higher DNA damage level than PM at the higher tested dose (100X) for both oyster spermatozoa and embryos. However, combination of copper and mixture of pesticides did not significantly increase DNA damage in comparison to copper exposure alone. Zhou et al. (2006) observed, that synergistic effects of binary mixture of antifouling chemicals and copper in Vibrio fischeri were due to the presence of $\mathrm{Cu}^{2+}$. These authors suggested that $\mathrm{Cu}$ could induce the formation of more lipophilic organic copper complexes, which diffused across the plasma membrane more easily. The mix of $\mathrm{PM}+\mathrm{Cu}$ could give rise to chemical complexes that could influence the bioavailability and the activity of mixture components (Dinku et al. 2003; Metcalfe et al. 2006; Singh et al. 2002). In addition, Rouimi et al. (2012) 
reported that mixtures of pesticides (atrazine, chlorpyrifos and endosulfan) could inhibit the cleavage of the PARP protein involved in DNA repair and programmed cell death processes.

A great proportion of sperm DNA damage (19.3-22.6\% tail DNA) was observed from the lowest tested dose $(0.1 \mathrm{X})$ for $\mathrm{PM}$ and $\mathrm{PM}+\mathrm{Cu}$ exposures, compared to the control group (7.2\% tail DNA). Deleterious effects of trace metals $(\mathrm{Cu}, \mathrm{Zn}, \mathrm{Cd})$ and organic xenobiotics (phenol, PCB, butyltin) on sperm cells are well documented for several invertebrate species such as sea urchin, mussel and oyster (Au et al. 2000, 2003; Yurchenko et al. 2009), but not in mixtures. Au et al. (2000) reported that low concentrations of individual trace metals or organic substances can induce ultra-structure abnormalities in spermatozoa of mussel and sea urchin. In addition, exposure to neonicotinoid pesticides has also been shown to alter chromatin structure of sperm cells (Gu et al. 2013; Ramazan et al. 2012). Gharred et al. (2015) also reported that sea urchin sperm cells (Paracentrotus lividus) exposed to a mixture of copper and deltamethrin show a high increase in mitotic division and asymmetric and/or asynchronous cell divisions. Therefore, $\mathrm{PM}$ or $\mathrm{PM}+\mathrm{Cu}$ mixtures could lead to higher toxicity, even if each individual toxicant in mixtures are present at very low concentrations (less than $10 \mathrm{ng} \mathrm{L}^{-1}$ for individual pesticides). However, Manzo et al. (2008) also observed antagonistic effects of a ternary mixture of two antifouling chemicals and copper in sperm cells of the sea urchin Paracentrotus lividus. Sperm DNA damage induction has been also associated with high levels of reactive oxygen species (Tamburrino et al. 2012; Zini and Libman 2006). However, the functional relationship between reaction oxygen species production and DNA damage induction has never been demonstrated in oyster sperm. Sperm cells are generally considered to have little capacity for DNA repair (Lacaze et al. 2011; Lewis and Galloway 2009). Spermatozoa are therefore considered a sensitive target for genotoxic compounds, and sperm DNA integrity is pointed out as one of the major risk factors for abnormal development of progeny and for the reduction in the number of offspring.

\subsection{Gene expression}

The rapid evolution of molecular techniques has led to a new approach in environmental science and risk assessment to link molecular and ecotoxicological responses. A well-founded identification and understanding of underlying molecular mechanisms will lead to a more effective risk assessment (Amiard et al. 2006; Watanabe et al. 2007). Here, we applied molecular tools to investigate stress responses in oyster embryos exposed to a pesticide mixture with and without copper. Eleven genes known to be involved in antioxidant defences, mitochondrial metabolism, detoxification, biotransformation process, and cell cycle arrest and 
apoptosis were investigated by quantitative real-time PCR. Several of these genes showed significant transcription modulation after exposure to either $\mathrm{PM}$ or $\mathrm{PM}+\mathrm{Cu}$ exposures. It is worth nothing that a lot of genes were downregulated following $\mathrm{PM}$ or $\mathrm{PM}+\mathrm{Cu}$ exposures such as p53, coxI, mt and cat. Those genes could be the first targets towards major disruptions to cell homoestasis (Asselman et al. 2012; Pereira et al. 2010; Dondero et al. 2006; Banerjee et al. 2001; Liu and Kulesz-Martin 2001).

This study has shown that oyster embryos exposed to PM and PM+Cu exhibited significant repression of the $p 53$ gene. For instance, the expression of $p 53$ gene was significantly reduced after a $24 \mathrm{~h}$ exposure to either $\mathrm{PM}$ or $\mathrm{PM}+\mathrm{Cu}$ at almost all tested concentrations. p53 protein is involved in key cellular processes such as cell cycle control, DNA repair and apoptosis (Elmore 2007; Liu and Kulesz-Martin 2001). p53 protein expression and function are tightly controlled by a feedback loop involving at least MDM2 protein (Wu et al. 1993). Some authors reported the inactivation of p53 protein after exposure of human HepG2 cells to copper or other agents that induce oxidative damage (Tassabehji et al. 2005). According to Hainaut and Milner (1993), redox conditions in cells influence the conformational folding of p53 protein, through oxidation/reduction of specific thiol groups (-SH) in its DNA binding domain. Sandrini et al. (2009) reported that the repression of $p 53$ gene could be explained by the inhibition of p53 protein due to a direct interaction with copper or indirect synergistic effect through ROS oxidation of the thiol $(-\mathrm{SH})$ residues.

Expression of coxI gene was strongly repressed at higher doses of $\mathrm{PM}+\mathrm{Cu}$. Given that the COXI protein is involved in the electron transport chain, our results suggest that mitochondrial metabolism can be affected by pesticides exposure. The number of copies of $12 s$ ARNm is indicative of the amount of mitochondria per cell. The ratio coxI/12s can be used as an indicator of relative changes in the number of mitochondria. This ratio did show significant lower values in exposed embryos than in control embryos $(\mathrm{p}<0.05)$ (Table 5). Pereira et al. (2010) reported that pesticides could affect the transcription of mitochondrial proteins and ATP synthesis-related proteins.

Ringwood and Brouwer (1995) and Roesijadi et al. (1996) have shown that embryos of Crassostrea sp. were able to induce metallothionein synthesis after exposure to trace metals such as copper and cadmium. A comprehensive review of the multifaceted role of metallothioneins emphasized that the metals, $\mathrm{Zn}, \mathrm{Cu}, \mathrm{Cd}, \mathrm{Hg}, \mathrm{Au}$ and $\mathrm{Bi}$ all induce $\mathrm{MT}$ synthesis (Coyle et al. 2002). Unexpectedly, in this study $m t 1$ and $m t 2$ gene transcriptions were strongly repressed in embryos exposed to both $\mathrm{PM}$ and $\mathrm{PM}+\mathrm{Cu}$, except for the lowest 
tested dose of $0.1 \mathrm{X} \mathrm{PM}+\mathrm{Cu}\left(100 \mathrm{ng} \mathrm{L}^{-1} \mathrm{Cu}\right.$ and from $0.1 \mathrm{ng} \mathrm{L}^{-1}$ to $45 \mathrm{ng} \mathrm{L}^{-1}$ of each pesticide). In addition, when oyster embryos were exposed to copper only, no modulation of gene expression was observed for genes $m t 1$ and $m t 2$. Recently, Asselman et al. (2012) reported that the $m t l$ expression was influenced by herbicide exposure regardless the concentrations. We hypothesize that the repression of genes $m t 1$ and $m t 2$ may be due to toxic effects of pesticides on oyster embryos. The expression ratio shows that $m t 1$ and $m t 2$ genes were repressed at the same level. This result could suggest that $m t 1$ and $m t 2$ genes are both targeted by pesticides and could play the same physiological roles in oyster embryos.

In the present study, gst gene transcription level tends to be overexpressed in oyster embryos exposed to $\mathrm{PM}$ and $\mathrm{PM}+\mathrm{Cu}$. GST protein is involved in xenobiotic metabolization by the formation of glutathione acetanilide conjugates (Lüdeking and Köhler 2002, Tanguy et al. 2005). Overexpression of this gene could be an adaptive response by oyster embryos to allow biotransformation and elimination of lipophilic xenobiotics such as certain pesticides.

Our experiments showed that cat gene transcription was significantly repressed by PM and/or $\mathrm{PM}+\mathrm{Cu}$ exposures, which could lead to a decrease of protection against oxidative stress. On the contrary, the cat gene was shown to be significantly up-regulated in mussels exposed to a copper contamination gradient (Dondero et al. 2006). Damiens et al. (2004) reported that CAT activity was inhibited in oyster larvae after exposure to pesticides. There is therefore evidence to suggest that pesticide mixtures with or without copper induce activation of the antioxidant systems resulting from an adaptive response to a likely oxidative stress in exposed oysters at an early life stage.

Finally, expression of genes encoding for proteins involved in anti-oxidative stress ( $g p x)$, multixenobiotic resistance $(m x r)$ and biotransformation process (cyplA) was unchanged regardless the doses of $\mathrm{PM}$ and $\mathrm{PM}+\mathrm{Cu}$ exposures compared with control groups. The basal expression levels of these genes may suggest either oyster embryos were not under stress or they were under stress but this set of genes were not specifically involved in response to pesticides or copper exposures in $C$. gigas oyster early life stages.

\section{Conclusion and perspectives}

Our experimental approach was consistent with environmental exposure conditions of oyster embryos living in polluted coastal areas chronically impacted by leaching from agricultural run-off. In this study, exposures of oyster embryos to pesticide mixtures with or 
without copper lead to developmental defects and DNA damage even at very low environmental concentrations. Changes in gene expression were mainly observed following exposure to pesticide mixture with or without $\mathrm{Cu}$ but not for $\mathrm{Cu}$ alone. Several genes involved in key cellular functions such as cell cycle control, mitochondria metabolism, anti-oxidative defence and metal detoxification were down regulated indicating likely major impact of pesticides on cell homeostasis.

To our knowledge, this study is one of the first to investigate the combined effects of mixtures of pesticides at environmentally relevant concentrations on embryos and sperm cells of Pacific oyster. In their natural habitat, organisms are exposed not only to mixtures of chemicals, but also to multiple stressors such as fluctuating physico-chemical parameters $\left(\mathrm{T}^{\circ} \mathrm{C}, \mathrm{pH}\right.$, oxygen, turbidity...) or infectious agents (bacteria, virus and parasites...). Therefore, for future studies, the combined effects/risk resulting from the interaction between chemical, physical and biological stressors should be taken into account.

\section{Acknowledgements}

The authors would like to acknowledge the French and Vietnamese Governments. This study was supported by the French National Research Agency, under reference "ANR- 09-CESA005”, Aquitaine Region (OSQUAR project) and CPER A2E. This project is co-financed by the European Union with the European fund of regional development. Finally, authors acknowledge James Emery for his help in English proofreading.

\section{References}

Akcha F, Spagnol C, Rouxel J (2012) Genotoxicity of diuron and glyphosate in oyster spermatozoa and embryos. Aquat Toxicol 106-107:104-113

Altenburger R, Nendza M, Schüürmann G (2003) Mixture toxicity and its modeling by quantitative structure-activity relationships. Environ Toxicol Chem 22(8):1900-1915

Amiard JC, Amiard-Triquet C, Barka S, Pellerin J, Rainbow PS (2006) Metallothioneins in aquatic invertebrates: Their role in metal detoxification and their use as biomarkers. Aquat Toxicol 76(2):160-202

Ansari MS, Moraiet MA, Salman Ahmad S (2014) Insecticides: Impact on the Environment and Human Health. In Malik A, Grohmann E, Akhtar R (eds) Environmental Deterioration 
475 and Human Health: Natural and Anthropogenic Determinants, Springer, Netherlands, pp 99$476 \quad 123$

477 Asselman J, Glaholt SP, Smith Z, Smagghe G, Janssen CR, Colbourne JK, Shaw JR De 478 Schamphelaere KAC (2012) Functional characterization of four metallothionein genes in 479 Daphnia pulex exposed to environmental stressors. Aquat Toxicol 110-111:54-65

480 Au DWT, Chiang MWL, Wu RSS (2000) Effects of Cadmium and Phenol on Motility and 481 Ultrastructure of Sea Urchin and Mussel Spermatozoa. Arch Environ Contamin Toxicol $482 \quad 38(4): 455-463$

483 Au DWT, Yurchenk, OV, Reunov AA (2003) Sublethal effects of phenol on spermatogenesis 484 in sea urchins (Anthocidaris crassispina). Environ Res 93(1) :92-98

485 Auby I, Bocquene G, Quiniou F, Dreno JP (2007) Etat de la contamination du Bassin 486 d'Arcachon par les insecticides et les herbicides sur la période 2005-2006. In Ifremer (ed) 487 Impact environnemental 24:108, pp 35. Available online at 488 http://archimer.ifremer.fr/doc/00000/2398/

Backhaus T, Arrhenius A, Blanck H (2004) Toxicity of a Mixture of Dissimilarly Acting 490 Substances to Natural Algal Communities: Predictive Power and Limitations of Independent Action and Concentration Addition. Environ Sci Technol 38(23):6363-6370

492 Banerjee BD, Seth V and Ahmed RS (2001) Pesticide-induced oxidative stress: perspectives 493 and trends. Reviews on Environmental Health 16(1), 1-40 Brooks SJ, Bolam T, Tolhurst L, Bassett J, La Roche J, Waldock M, Barry J, Thomas KV (2007) The effects of dissolved organic carbon on the toxicity of copper to the developing 496 embryos of the Pacific oyster, Crassostrea gigas. Environ Toxicol Chem.26:1756-1763

497

498 499

Bryan GW, Langston WJ (1992) Bioavailability, accumulation and effects of heavy metals in sediments with special reference to United Kingdom estuaries: a review. Environ Pollut $76(2): 89-131$

Budzinski H, Tapie N, Belles A (2011) Rapport REPAR: Quantification de la présence. Résultats des analyses chimiques sur prélèvements ponctuels. pp 1-15. http://www.sibabassin-arcachon.fr/node/635

Coyle P, Philcox JC, Carey LC, Rofe AM (2002) Metallothionein: the multipurpose protein. Cell Mol Life Sci 59(4):627-647 
505

506

507

508

509

510

511

512

513

514

515

516

517

518

519

520

521

522

523

524

525

526

527

528

529

530

531

532

533

Damiens G, His E, Gnassia-Barelli M, Quiniou F, Roméo M (2004) Evaluation of biomarkers in oyster larvae in natural and polluted conditions. Comparat Biochem Physiol Part C: Toxicol Pharmacol 138(2):121-128

Diepens NJ, Buffan-Dubau E, Budzinski H, Kallerhoff J, Merlina G, Silvestre J, Auby I, Tapie N, Elger A (2017) Toxicity effects of an environmental realistic herbicide mixture on the seagrass Zostera noltei. Environ Pollut 222:393-403. https://doi.org/10.1016/j.envpol.2016.12.021

Dinku W, Megersa N, Raju VJT, Solomon T, Jönsson JÅ,, Retta N (2003) Studies on transition metal complexes of herbicidal compounds. II: Transition metal complexes of derivatized 2-chloro-4-ethylamino-6-isopropylamino-s-triazine (atrazine). Bull Chem Soc Ethiopia 17(1):35-43

Dondero F, Dagnino A, Jonsson H, Capri F, Gastaldi L, Viarengo A (2006) Assessing the occurrence of a stress syndrome in mussels (Mytilus edulis) using a combined biomarker/gene expression approach. Aquat Toxicol 78(0):S13-S24

Elmore S (2007) Apoptosis: A Review of Programmed Cell Death. Toxicolo Pathol 35(4):495-516

Faust M, Altenburger R, Backhaus T, Blanck H, Boedeker W, Gramatica P, Hamer V, Scholze M, Vighi M, Grimme LH (2001) Predicting the joint algal toxicity of multicomponent s-triazine mixtures at low-effect concentrations of individual toxicants. AquatiToxicol 56(1):13-32

Fauvelle V, Mazzella N, Morin S, Moreira S, Delest B, Budzinski H (2015) Hydrophilic interaction liquid chromatography coupled with tandem mass spectrometry for acidic herbicides and metabolites analysis in fresh water. Environ Sci Pollut Res 22:3988-3996

Gagnaire B, Gay M, Huvet A, Daniel JY, Saulnier D, Renault T (2007) Combination of a pesticide exposure and a bacterial challenge: In vivo effects on immune response of Pacific oyster, Crassostrea gigas (Thunberg). Aquat Toxicol 84(1):92-102

Gagnaire B, Thomas-Guyon H, Burgeot T, Renault T (2006) Pollutant effects on Pacific oyster, Crassostrea gigas (Thunberg), hemocytes: Screening of 23 molecules using flow cytometry. Cell Biol Toxicol 22(1):1-14 
534 Gamain P., Gonzalez, P., Cachot, J., Pardon, P., Tapie, N., Gourves, P.Y., Budzinski, H., 535 Morin, B. (2016) Combined effects of pollutants and salinity on embryo-larval development of the Pacific oyster, Crassostrea gigas. Marine Environmental Research 113:31-38

537 Gamain P, Gonzalez P, Cachot J, Clerandeau C, Mazella N, Gourves PY, Morin B (2017a) 538 Combined effects of temperature and pollutants on embryo-larval development of the Pacific oyster, Crassostrea gigas. Marine Pollut Bull 115:201-210

540 Gamain P, Cachot J, Gonzalez P, Gourves PY, Budzinski H, Morin B (2017b) Do temporal and spatial parameters or lifestyle of the Pacific oyster Crasssostrea gigas broodstock native

542 from the Arcachon Bay (Southwest coast of France) affect pollutant bioaccumulation, 543 offspring development and tolerance to pollutants? Frontier in Marine Sci 544 https://doi.org/10.3389/fmars.2017.00058

545 Geffard O, Budzinski H, His E (2002) The Effects of Elutriates from PAH and Heavy Metal Polluted Sediments on Crassostrea gigas (Thunberg) Embryogenesis, Larval Growth and Bioaccumulation by the Larvae of Pollutants from Sedimentary Origin. Ecotoxicol 11(6):403-416 Gharred T, Ezzine IK, Naija A, Bouali RR, Jebali J (2015) Assessment of toxic interactions between deltamethrin and copper on the fertility and developmental events in the Mediterranean sea urchin, Paracentrotus lividus. Environ Monit Assess 187(4):1-8

551 Gilliom RJ (2007) Pesticides in U.S. streams and groundwater. Environ Sci Technol 41:3407552 3413

553

Gu YH, Li Y, Huang XF, Zheng JF, Yang J, Diao H, Yuan Y, Xu Y, Liu M, Shi HJ, Xu W (2013) Reproductive Effects of Two Neonicotinoid Insecticides on Mouse Sperm Function and Early Embryonic Development In Vitro. PLoS ONE 8(7):e70112

Hainaut P, Milner J (1993) Redox Modulation of p53 Conformation and Sequence-specific DNA Binding in Vitro. Cancer Res 53(19):4469-4473

558 Hernando MD, Ejerhoon M, Fernandez-Alba AR Chisti Y (2003) Combined toxicity effects 559 of MTBE and pesticides measured with Vibrio fischeri and Daphnia magna bioassays. Water 560 Res 37(17):4091-4098

561 His E, Beiras R, Seaman MNL, Southward PAT, Young CM (1999) Advances in Marine Biology, Academic Press, Elsevier. Jacobsen PR, Axelstad M, Boberg J, Isling LK, Christiansen S, Mandrup K., Berthelsen LO, Vinggaard AM, Hass U (2012) Persistent developmental toxicity in rat offspring after low 
565 dose exposure to a mixture of endocrine disrupting pesticides. Reproductive Toxicol 566 34(2):237-250

567 Jin-Clark Y, Anderson T, Zhu K (2008) Effect of Alachlor and Metolachlor on Toxicity of 568 Chlorpyrifos and Major Detoxification Enzymes in the Aquatic Midge, Chironomus tentans 569 (Diptera: Chironomidae). Arch Environ Contam Toxicol 54(4):645-652

570 Junghans M, Backhaus T, Faust M, Scholze M, Grimme LH (2003) Predictability of 571 combined effects of eight chloroacetanilide herbicides on algal reproduction. Pest Manag Sci 572 59(10):1101-1110

573 Komarek M, Cadkova E, Chrastný V, Bordas F, Bollinger JC (2010) Contamination of 574 vineyard soils with fungicides: a review of environmental and toxicological aspects. Environ 575 Int 36(1):138-51

576 Konstantinou IK, Albanis TA (2004) Worldwide occurrence and effects of antifouling paint 577 booster biocides in the aquatic environment. Environ Int 30:235-248.

578 Lacaze E, Geffard O, Goyet D, Bony S, Devaux A (2011). Linking genotoxic responses in 579 Gammarus fossarum germ cells with reproduction impairment, using the Comet assay. 580 Environ Res 111:626-634

581 Lamoree MH, Swart CP, van der Horst A, van Hattum B (2002) Determination of diuron and 582 the antifouling paint biocide Irgarol 1051 in Dutch marinas and coastal waters. J Chromatogr 583 A 970:183-190

584 Legorburu I, Canton L (1991) Heavy metal concentration in sediments from Pasajes Harbour, 585 Spain. Mar Pollut Bull 22(4):207-209 Lewis C, Galloway T.(2009) Reproductive Consequences of Paternal Genotoxin Exposure in 587 Marine Invertebrates. Environ Sci Technol 43:928-933

588 Lissalde S, Mazzella N, Fauvelle V, Delmas F, Mazellier P, Legube B (2011) Liquid 589 chromatography coupled with tandem mass spectrometry method for thirty-three pesticides in 590 natural water and comparison of performance between classical solid phase extraction and 591 passive sampling approaches. J Chromatogr A 1218:1492-1502

592 Liu Y, Kulesz-Martin M (2001) p53 protein at the hub of cellular DNA damage response 593 pathways through sequence-specific and non-sequence-specific DNA binding. Carcinog 594 22(6):851-860 
595

596

597

598

599

600

601

602

603

604

605

606

607

608

609

610

611

612

613

614

615

616

617

618

619

620

621

622

623

624

Livak KJ, Schmittgen TD (2001) Analysis of Relative Gene Expression Data Using RealTime Quantitative PCR and the 2- $\Delta$ Ct Method. Methods 25(4):402-408

Lüdeking A, Köhler A (2002) Identification of six mRNA sequences of genes related to multixenobiotic resistance (MXR) and biotransformation in Mytilus edulis. Marine Ecol Progress Series 238:115-124

Mai H, Cachot J, Brune J, Geffard O, Belles A, Budzinski H, Morin B (2012) Embryotoxic and genotoxic effects of heavy metals and pesticides on early life stages of Pacific oyster (Crassostrea gigas). Mar Pollut Bull 64(12):2663-2670

Mai H, Morin B, Pardon P, Gonzalez P, Budzinski H, Cachot J (2013) Environmental concentrations of irgarol, diuron and S-metolachlor induce deleterious effects on gametes and embryos of the Pacific oyster, Crassostrea gigas. Mar Environ Res 89(0):1-8

Manzo S, Buono S, Cremisini C (2006) Toxic Effects of Irgarol and Diuron on Sea Urchin Paracentrotus lividus Early Development, Fertilization, and Offspring Quality. Arch Environ Contam Toxicol 51(1):61-68

Martinez K, Ferrer I, Hernando MD, Fernandez-Alba AR, Marce RM, Borrull F, Barcelo D (2001) Occurrence of antifouling biocides in the Spanish Mediterranean marine environment. Environ Technol 22:543-552

Manzo S, Buono S, Cremisini C (2008) Predictability of Copper, Irgarol, and Diuron Combined Effects on Sea Urchin Paracentrotus lividus. Arch Environ Contam Toxicol 54(1):57-68

Metcalfe C, Rajput C, Thomas JA (2006) Studies on the interaction of extended terpyridyl and triazine metal complexes with DNA. J Inorga Biochem 100(8):1314-1319

Monosson E (2004) Chemical Mixtures: Considering the Evolution of Toxicology and Chemical Assessment. Environ Health Perspect 113(4):383-390

Morin B, Filatreau J, Vicquelin L, Barjhoux I, Guinel S, Leray-Forget J, Cachot J (2011) Detection of DNA damage in yolk-sac larvae of the Japanese Medaka, Oryzias latipes, by the comet assay. Anal Bioanal Chem 399(6):2235-2242

Pereira JL, Hill CJ, Sibly RM, Bolshakov VN, Goncalves F, Heckmann LH, Callaghan A (2010) Gene transcription in Daphnia magna: Effects of acute exposure to a carbamate insecticide and an acetanilide herbicide. Aquat Toxicol 97(3):268-276 
625 Poletta GL, Kleinsorge E, Paonessa A, Mudry MD, Larriera A, Siroski PA (2011) Genetic,

626

627

628

629

630

631

632

633

634

635

636

637

638

639

640

641

642

643

644

645

646

647

648

649

650

651

652

653

654 enzymatic and developmental alterations observed in Caiman latirostris exposed in ovo to pesticide formulations and mixtures in an experiment simulating environmental exposure. Ecotoxicol Environ Saf 74(4):852-859

Ramazan B, Gaffari T, Ökkeş Y, Ebru E, Tuncay K, Gıyasettin B, Mustafa N (2012) Effects of clothianidin exposure on sperm quality, testicular apoptosis and fatty acid composition in developing male rats. Cell Biol Toxicol 28(3):187-200

Ranke J, Jastorff B (2000) Multidimensional risk analysis of antifouling biocides. Environ Sci Pollut Res 7(2):105-114

Ringwood AH, Brouwer M (1995) Patterns of metallothionein expression in oyster embryos. Mar Environ Res 39(1-4):101-105

Roesijadi G, Hansen KM, Unger ME (1996) Cadmium-Induced Metallothionein Expression during Embryonic and Early Larval Development of the Mollusc Crassostrea virginica. Toxicol Appl Pharmacol 140(2):356-363

Rouimi P, Zucchini-Pascal N, Dupont G, Razpotnik A, Fouché E, De Sousa G, Rahmani R (2012) Impacts of low doses of pesticide mixtures on liver cell defence systems. Toxicol In Vitr 26(5):718-726

Sandrini JZ, Bianchini A, Trindade GS, Nery L, Marins LFF (2009) Reactive oxygen species generation and expression of DNA repair-related genes after copper exposure in zebrafish (Danio rerio) ZFL cells. Aquat Toxicol 95(4):285-291. https:// doi.org/10.1016/j.aquatox.2009.02.016.

Silva E, Rajapakse N, Kortenkamp A (2002) Something from "Nothing" - Eight Weak Estrogenic Chemicals Combined at Concentrations below NOECs Produce Significant Mixture Effects. Environ Sci Technol 36(8):1751-1756

Singh G, Singh PA, Sen AK, Singha K, Dubeya SN, Handa RN, Choi J (2002) Synthesis and characterization of some bivalent metal complexes of schiff bases derived from as-triazine. Synth React Inorg Met Org Chem 32(1):171-187

Tamburrino L, Marchiani S, Montoya M, Elia Marino F, Natali I, Cambi M, Forti G, Baldi E, Muratori M (2012) Mechanisms and clinical correlates of sperm DNA damage. Asian J Androl 14(1):24-31 
655

656

657

658

659

660

661

662

663

664

665

666

667

668

669

670

671

672

673

674

675

676

677

678

679

680

681

682

683

684

Tanguy A, Boutet I, Laroche J, Moraga D (2005) Molecular identification and expression study of differentially regulated genes in the Pacific oyster Crassostrea gigas in response to pesticide exposure. FEBS Lett 272(2):390-403

Tassabehji NM, VanLandingham JW Levenson CW (2005) Copper Alters the Conformation and Transcriptional Activity of the Tumor Suppressor Protein p53 in Human Hep G2 Cells. Exp Biol Med 230(10):699-708

Thomas KV, Brooks S (2010) The environmental fate and effects of antifouling paint biocides. Biofouling 26:73-88

van der Oost R, Goksoyr A, Celander M, Heida H, Vermeulen NPE (1996) Biomonitoring of aquatic pollution with feral eel (Anguilla anguilla) II. Biomarkers: pollution-induced biochemical responses. Aquat Toxicol 36(3-4):189-222

Verslycke T, Vangheluwe M, Heijerick D, De Schamphelaere K, Van Sprang P, Janssen CR (2003) The toxicity of metal mixtures to the estuarine mysid Neomysis integer (Crustacea: Mysidacea) under changing salinity. Aquat Toxicol 64(3):307-315

Vischetti C, Marini M, Businelli M, Onofri A (1996) The Effect of Temperature and Coapplied Herbicides on the Degradation Rate of Phenmedipham, Chloridazon and Metamitron in a Clay Loam Soil in the Laboratory. X Symposium Pesticide Chemistry. The Environmental Fate of Xenobiotics, September 30 - October 2. Castelnuovo Fogliani, Piacenza, Italy pp 287-294

Watanabe H, Takahashi E, Nakamura Y, Oda S, Tatarazako N, Iguchi T (2007) Development of a daphnia magna DNA microarray for evaluating the toxicity of environmental chemicals. Environ Toxicol Chem 26(4):669-676

Wessel N, Rousseau S, Caisey X, Quiniou F, Akcha F (2007) Investigating the relationship between embryotoxic and genotoxic effects of benzo[a]pyrene, 17[alpha]-ethinylestradiol and endosulfan on Crassostrea gigas embryos. Aquat Toxicol 85(2):133-142

Wu X, Bayle JH, Olson D, Levine AJ (1993) The p53-mdm-2. Autoregulatory feedback loop. Genes Dev 7 (7):1126-1132

Yurchenko O, Radashevsky V, Hsieh HL, Reunov A (2009) Ultrastructural comparison of the spermatozoa of the Pacific oyster Crassostrea gigas inhabiting polluted and relatively clean areas in Taiwan. Aquat Ecol 43(2):513-519 
685 Zhou X, Okamura H, Nagata S (2006) Remarkable Synergistic Effects in Antifouling 686 Chemicals against Vibrio fischeri in a Bioluminescent Assay. J Health Sci 52(3):243-251

687 Zini A, Libman J (2006) Sperm DNA damage: clinical significance in the era of assisted 688 reproduction.

Can

Med

Assoc

$\mathrm{J}$

175(5):495-500 


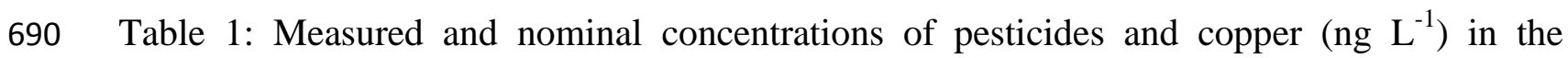
691 different pesticide mixtures tested

\begin{tabular}{|c|c|c|c|c|c|c|}
\hline & $\begin{array}{l}\text { Control } \\
\text { (FSW) }\end{array}$ & $0.1 \mathrm{X}$ & $\begin{array}{l}1 \mathrm{X}^{*} \text { (nominal } \\
\text { concentration) }\end{array}$ & $1 X^{*}$ & $10 X$ & $100 \mathrm{X}$ \\
\hline Acetochlor & 1 & 3 & 5 & 8 & 48 & 513 \\
\hline Acetochlor ESA & $<5$ & 57 & 450 & 404 & 3466 & 34061 \\
\hline Acetochlor OA & $<5$ & $<5$ & 50 & 17 & 84 & 862 \\
\hline Metolachlor & 13 & 23 & 30 & 21 & 74 & 952 \\
\hline Metolachlor ESA & 7 & 57 & 450 & 231 & 3778 & 25201 \\
\hline Metolachlor OA & $<2$ & 53 & 450 & 273 & 4219 & 28795 \\
\hline Diuron & 1 & 3 & 5 & 5 & 40 & 415 \\
\hline Irgarol & 2 & 2 & 5 & 5 & 37 & 369 \\
\hline Hydroxy-atrazine & $<1$ & 1 & 15 & 28 & 185 & 1728 \\
\hline Imidacloprid & $<5$ & 14 & 80 & 83 & 684 & 7516 \\
\hline Carbendazim & $<0.5$ & $<0.5$ & 5 & 3 & 5 & 3 \\
\hline Chlorothalonil & na & $0.1^{\mathrm{a}}$ & 1 & $1^{\mathrm{a}}$ & $10^{\mathrm{a}}$ & $100^{\mathrm{a}}$ \\
\hline Dichlofluanid & na & $0.1^{\mathrm{a}}$ & 1 & $1^{\mathrm{a}}$ & $10^{\mathrm{a}}$ & $100^{\mathrm{a}}$ \\
\hline DMST & $<2$ & $<2$ & 10 & 5 & 69 & 1508 \\
\hline $\mathrm{Cu}$ & 3160 & 4180 & 2000 & 6330 & 23500 & 199000 \\
\hline
\end{tabular}


695 Table 2: Nucleotide sequences of primers used in real-time PCR analysis of $C$. gigas larvae

\begin{tabular}{|c|c|c|c|}
\hline $\begin{array}{l}\text { Gene function } \\
\text { and name }\end{array}$ & $\begin{array}{l}\text { Accession } \\
\text { number }\end{array}$ & Forward primer & Reverse primer \\
\hline \multicolumn{4}{|l|}{$\begin{array}{l}\text { Mitochondrial } \\
\text { metabolism }\end{array}$} \\
\hline $12 S$ & AF034688 & CTCAGTCTTGCGGGAGG & GGTTATGCGGAACCGCC \\
\hline $\operatorname{cox} 1$ & AB033687 & GTGCCAACTGGTATTAAGGTGT & ACACCGCACCCATTGAT \\
\hline \multicolumn{4}{|l|}{$\begin{array}{l}\text { Oxidative stress } \\
\text { response }\end{array}$} \\
\hline cat & EF687775.1 & GTCGTGCCCCTTTACAACC & CGCCCGTCCGAAGTTT \\
\hline sodmt & EU420128 & ACAAAGTCAATCAGTGCCCT & CCATTGCCTCTGCCAGT \\
\hline$g p x$ & EF692639 & ATCGAACGCTGCACCA & AGCTCCGTCGCATTGT \\
\hline \multicolumn{4}{|l|}{ Detoxification } \\
\hline mt1 & AJ242657 & TGTCTGCTCTGATTCGTGTCC & GGTCCTTTGTTACACGCACTCATT \\
\hline$m+2$ & AJ297818 & TCCGGATGTGGCTGCAAAGTCAAG & GGTCCTTTGTTACACGCACTCATT \\
\hline$m \times r$ & AJ422120 & AGGAAGGGCAGTTGAGTG & CGTTGGCCTCCTTAGCG \\
\hline \multicolumn{4}{|l|}{ Metabolization } \\
\hline cyp1A1 & EF645271 & AGGCATAGGGCTCCCAC & CTGGTTTCGCGGGTTTCAT \\
\hline gst & AJ557140 & AGGCTACCGAAATGGCTG & CTCTGACTTGTAATAGGCCGC \\
\hline \multicolumn{4}{|l|}{ Cell regulation } \\
\hline P53 & AM236465 & CCCTCAAAGCAGTCCCCA & TGTAGCGATCCACCTGATT \\
\hline \multicolumn{4}{|l|}{ Reference } \\
\hline 6-actin & AB071191 & AGTACCCCATTGAACACGG & TGGCGGGAGCGTTGAA \\
\hline
\end{tabular}

696 Abbreviations: $m t$ : metallothionein; coxI: cytochrome C oxidase subunit I; gpx: glutathione peroxidase; sod: 697 superoxide dismutase; cat: catalase; sodmt: mitochondrial superoxide dismutase; mxr: multixenobiotic 698 resistance, gst: glutathione S transferase, cyp: cytochrome P450. 
701 Table 3: $\mathrm{EC}_{50}$ values ( $\pm \mathrm{CI} 95 \%$ ) obtained with the oyster embryo-larval assay for $\mathrm{Cu}$ alone, 702 pesticide mixture and pesticide mixture plus $\mathrm{Cu}$.

703

Compounds $\quad$ EC $_{50}$ value

\begin{tabular}{ll}
\hline $\mathrm{Cu}\left(\mathrm{ng} \mathrm{L}^{-1}\right)$ & $12,500(11,000-14,200)^{\mathrm{a}}$ \\
\hline Pesticide mixture & $5.2 \mathrm{X}(2.8 \mathrm{X}-9.9 \mathrm{X})$ \\
Pesticide mixture $+\mathrm{Cu}$ & $0.7 \mathrm{X}(0.2 \mathrm{X}-2.0 \mathrm{X})$
\end{tabular}

704 Note: $1 \mathrm{X}$ was set at $1,085 \mathrm{ng} \mathrm{L}^{-1}$ for the sum of all tested pesticides and $6,330 \mathrm{ng} \mathrm{L}^{-1}$ for copper.

$705{ }^{a}$ Mai et al. (2012)

706 
708 Table 4: Induction factors (IF) of gene transcription for the eleven studied genes in oyster D709 larvae following a 24h-exposure to copper alone or to pesticide mixture with or without 710 copper ( $\mathrm{N}=3$ for each treatment condition).

\begin{tabular}{|c|c|c|c|c|c|c|c|c|c|c|}
\hline \multirow[t]{2}{*}{ Functions } & \multirow[t]{2}{*}{ Genes } & \multicolumn{3}{|c|}{ Copper } & \multicolumn{3}{|c|}{ Pesticide mixture } & \multicolumn{3}{|c|}{ Pesticide mixture $+\mathrm{Cu}$} \\
\hline & & $0.1 \mathrm{X}$ & $1 X$ & $10 \mathrm{X}$ & $0.1 \mathrm{X}$ & $1 \mathrm{X}$ & $10 \mathrm{X}$ & $0.1 \mathrm{X}$ & $1 \mathrm{X}$ & $10 \mathrm{X}$ \\
\hline $\begin{array}{l}\text { Cells cycle } \\
\text { arrest/apoptosis }\end{array}$ & p53 & / & / & / & $0.3 *$ & $0.3 *$ & $0.4^{*}$ & $0.3 *$ & / & $0.4^{*}$ \\
\hline \multirow{2}{*}{$\begin{array}{l}\text { Mitochondrial } \\
\text { metabolism }\end{array}$} & $12 s$ & I & I & I & l & I & I & I & I & I \\
\hline & $\operatorname{cox} I$ & I & I & l & $0.3^{*}$ & $0.3^{*}$ & $0.4^{*}$ & l & $0.3^{*}$ & $0.3^{*}$ \\
\hline \multirow{3}{*}{$\begin{array}{l}\text { Oxidative stress } \\
\text { response }\end{array}$} & sodmt & / & / & / & / & / & / & / & / & / \\
\hline & cat & I & I & I & $0.02 *$ & $0.1 *$ & / & $0.2 *$ & $0.4 *$ & $0.1 *$ \\
\hline & $g p x$ & / & / & / & / & / & / & / & / & / \\
\hline \multirow{3}{*}{$\begin{array}{l}\text { Metal } \\
\text { detoxification }\end{array}$} & $m t 1$ & / & / & / & $0.03^{*}$ & $0.04 *$ & $0.1^{*}$ & I & $0.1^{*}$ & $0.04 *$ \\
\hline & $m+2$ & I & I & / & $0.04 *$ & $0.1^{*}$ & $0.1^{*}$ & / & $0.1 *$ & $0.04^{*}$ \\
\hline & $m x r$ & / & / & / & / & / & / & / & / & / \\
\hline Xenobiotic & $g s t$ & I & l & I & I & I & I & $5.5^{*}$ & $3.1 *$ & $3.1^{*}$ \\
\hline biotransformation & cyp1A & I & I & $1.8^{*}$ & I & / & I & I & I & / \\
\hline
\end{tabular}

711 The results are given in the form of induction $(>2.0)$ or repression $(<0.5)$ compared to control group.

712 Asterisks indicate significant difference in gene transcription level between exposed and control

713 treatments by Tukey's test $(\mathrm{p}<0.05)$. The sign / means no significant change in gene expression 714 compared to control. 
717 Table 5: Expression ratios of coxI/ $12 s$ and $m t 2 / m t 1$ in oyster embryos after a $24 \mathrm{~h}$-exposure to

718 pesticide mixture, or pesticide mixture $+\mathrm{Cu}$, or $\mathrm{Cu}$ alone

719

\begin{tabular}{|c|c|c|c|c|c|c|c|c|c|}
\hline \multirow[t]{2}{*}{ Expression ratio } & \multicolumn{3}{|l|}{$\mathbf{C u}$} & \multicolumn{3}{|c|}{ Pesticide mixture } & \multicolumn{3}{|c|}{ Pesticide mixture $+\mathrm{Cu}$} \\
\hline & $0.1 \mathrm{X}$ & $1 \mathrm{X}$ & $10 \mathrm{X}$ & $0.1 \mathrm{X}$ & $1 \mathrm{X}$ & $10 \mathrm{X}$ & $0.1 \mathrm{X}$ & $1 \mathrm{X}$ & $10 \mathrm{X}$ \\
\hline $\operatorname{coxI} / 12 s$ & 1.9 & 1.6 & 1.3 & $0.2 *$ & $0.1^{*}$ & $0.2^{*}$ & $0.2 *$ & $0.1^{*}$ & $0.2^{*}$ \\
\hline$m t 2 / m t 1$ & 0.8 & 1.0 & 0.9 & 1.1 & 1.0 & 1.0 & 1.4 & 1.0 & 1.0 \\
\hline
\end{tabular}

720 Asterisks indicate significant difference between exposed and control treatments (Tukey's test, $\mathrm{p}<$ $7210.05)$

722 


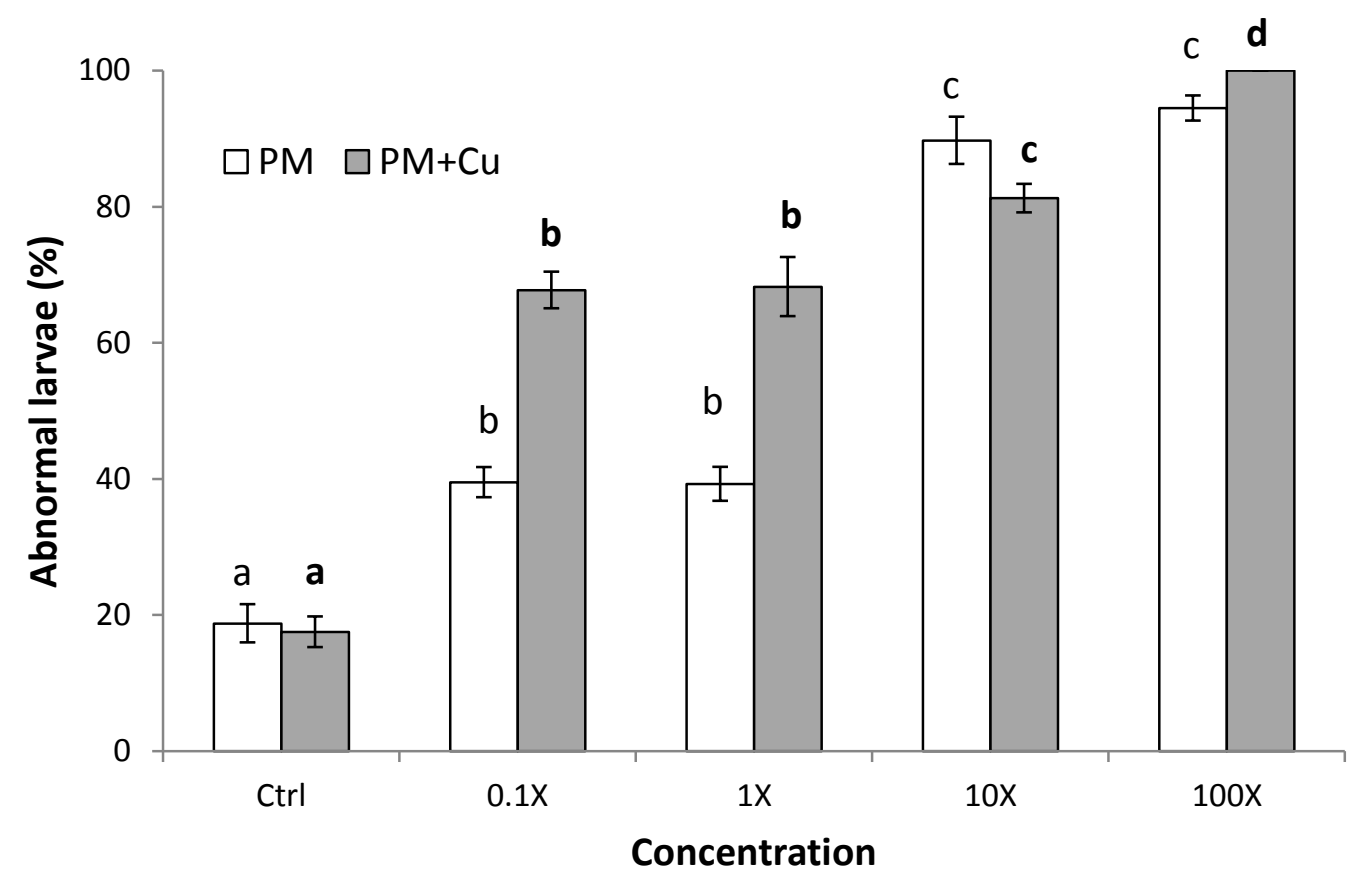

724

725 Fig.1: Developmental abnormalities in oyster D-larvae following a 24h-exposure to pesticide 726 mixture $(\mathrm{PM})$ and pesticide mixture in combination with copper $(\mathrm{PM}+\mathrm{Cu})$. Different letters

727 indicate significant differences between treatments $(\mathrm{N}=4, \mathrm{p}<0.0001$, Tukey’s test).

728

729

730

731

732

733

734 


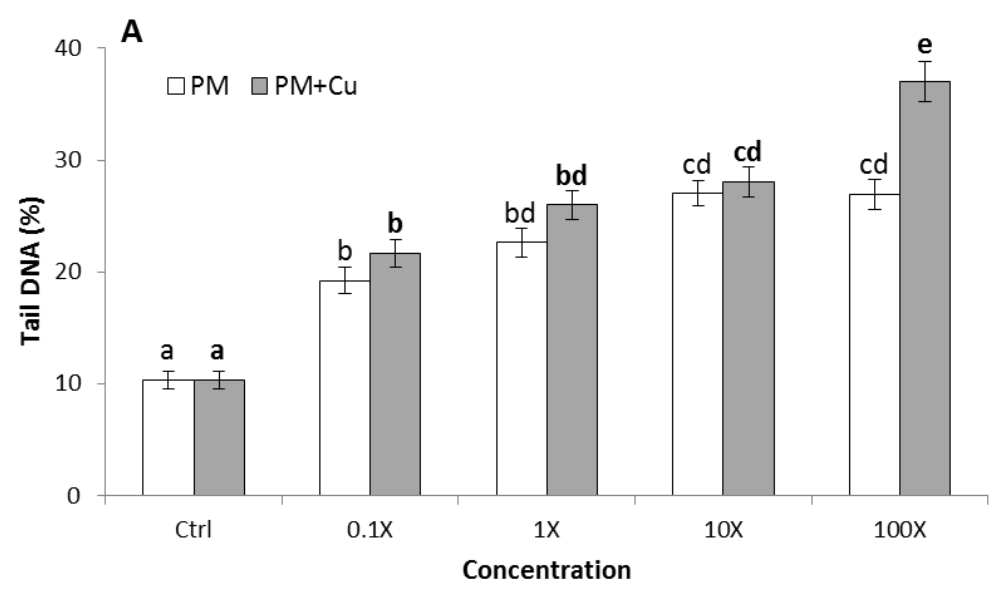

735

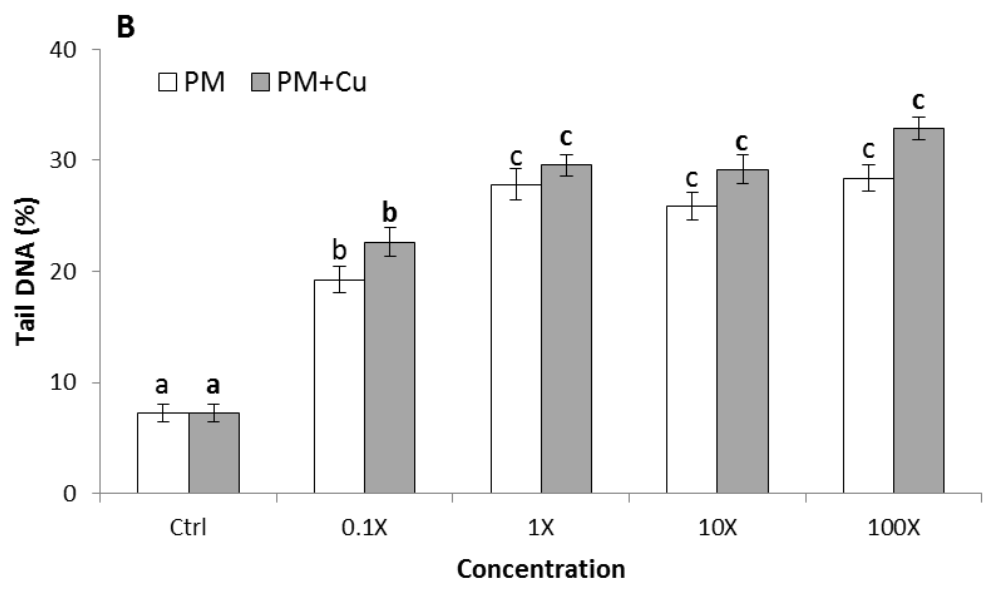

736

737 Fig.2: Percentages (Mean \pm S.E.) of tail DNA in A) oyster larvae following a 16h-exposure or 738 B) oyster sperm after 30 min-exposure to pesticide mixture (PM) and pesticide mixture in 739 combination with copper $(\mathrm{PM}+\mathrm{Cu})$. Different letters indicate significant differences between 740 treatments $(\mathrm{N}=3, \mathrm{p}<0.001$, Tukey's test $)$. 